\title{
Article/Artigo
}

\section{Variation in Aedes aegypti (Linnaeus) (Diptera, Culicidae) infestation in artificial containers in Caxias, State of Maranhão, Brazil}

\author{
Variação da infestação de Aedes aegypti (Linnaeus), (Diptera, Culicidae) em recipientes \\ artificiais em Caxias, Estado do Maranhão, Brasil
}

\author{
Joelma Soares-da-Silva ${ }^{1,2,3}$, Sebastiana Silva Ibiapina ${ }^{2}$,Juliana Maria Trindade Bezerra ${ }^{2,4}$, Wanderli Pedro Tadei ${ }^{3}$, \\ and Valéria Cristina Soares Pinheiro ${ }^{2,5}$
}

\begin{abstract}
Introduction: Dengue is a serious public health problem worldwide, with cases reported annually in tropical and subtropical regions. Aedes aegypti (Linnaeus, 1762), the main vector of dengue, is a domiciliary species with high dispersal and survival capacities and can use various artificial containers as breeding sites. We assessed potential container breeding sites of A. aegypti in the municipality of Caxias, Maranhão, Brazil. Methods: In the initial phase, we analyzed 900 properties in 3 neighborhoods during the dry and rainy seasons (AugustOctober 2005 and February-April 2006, respectively). During the second sampling period, September 2006-August 2007, we used 5 assessment cycles for 300 properties in a single neighborhood. Results: During the dry and rainy seasons, water-storage containers comprised $55.7 \%(\mathrm{n}=1,970)$ and $48.5 \%(\mathrm{n}=1,836)$ of the total containers inspected, and showed the highest productivity of immature A. aegypti; we found 23.7 and 106.1 individuals/container, respectively, in peridomicile sites. In intradomicile sites, water-storage containers were also the most important breeding sites with $86.4 \%(\mathrm{n}=973)$ and $85.6 \%(\mathrm{n}=900)$ of all containers and a mean of 7.9 and 108.3 individuals/container in the dry and rainy seaso-October 2006 $(1,342)$. The highest number of positives (70) was recorded in May, mostly (94\%) in storage containers. Conclusions: Storage containers are the principal and most productive A. aegypti breeding sites and are a major contributing factor to the maintenance of this vector in Caxias. Keywords: Dengue. Vector. Prevention. Control. Containers.
\end{abstract}

\section{RESUMO}

Introdução: A dengue constitui de um sério problema de saúde pública mundial, com casos sendo registrados anualmente nas regiões tropicais e subtropicais. O Aedes aegypti (Linnaeus, 1762) é o principal vetor da doença, um mosquito domiciliado de fácil dispersão e sobrevivência, com capacidade de utilizar variados recipientes artificiais como criadouro. Em vista disso, neste trabalho investigou-se os tipos de recipientes potenciais criadouros de A. aegypti na Cidade de Caxias, Maranhão, Brasil. Métodos: Inicialmente, a pesquisa foi desenvolvida em três bairros e 900 imóveis analisados no período da seca e das chuvas (agosto a outubro de 2005 e fevereiro a abril de 2006, respectivamente). Um segundo período de amostragem ocorreu de setembro de 2006 a agosto de 2007 em que inspeções de cinco ciclos foram desenvolvidas em um dos bairros com 300 imóveis amostrados. Resultados: Os recipientes de armazenamento de água representaram 55,7\% ( $n=1.970)$ e 48,5\% $(n=1.836)$ do total dos inspecionados, e maior produtividade de imaturos de $A$. aegypti, com proporção de 23,7 e 106,1 por recipiente no peridomicílio, nas estações seca e chuvosa respectivamente. No intradomicílio, também foi mais representativo, $86,4 \%(n=973)$ e $84,6 \%(n=900)$, apresentando média de 7,9 e 108,3 indivíduos, nas duas estações. O maior número de recipientes com água foi registrado em setembro e outubro 2006 (1.342), obtendo-se maior número de positivos (70) no mês de maio, sendo (94\%) pertencentes ao grupo armazenamento. Conclusões: Armazenamento são os principais criadouros de $A$. aegypti, contribuindo na manutenção do vetor na cidade de Caxias, Maranhão.

Palavras-chaves: Dengue. Vetor. Prevenção. Controle. Recipientes.

1. Divisão de Curso de Entomologia, Instituto Nacional de Pesquisas da Amazônia, Manaus, AM. 2. Laboratório de Entomologia Médica, Centro de Estudos Superiores de Caxias, Universidade Estadual do Maranhão, Caxias, MA. 3. Laboratório de Malária e Dengue, Instituto Nacional de Pesquisas da Amazônia, Manaus, AM. 4. Centro de Pesquisa René Rachou, Fundação Oswaldo Cruz, Belo Horizonte, MG. 5. Programa de Pós-Graduação em Saúde Materno-Infantil, Universidade Federal do Maranhão, São Luís, MA.

Address to: Dra. Valéria Cristina Soares Pinheiro. LABEM/Dept ${ }^{\circ}$ de Biologia e Química/CESC/UEMA. Praça Duque de Caxias s/n, Morro do Alecrim, 65600-000 Caxias, MA, Brasil.

Phone: 5599 3521- 3888

e-mail:vc_pinheiro@hotmail.com

Received in 24/03/2011

Accepted in 11/11/2011

\section{INTRODUCTION}

In recent years, Brazil has reported a high proportion of the world's dengue cases ${ }^{1,2}$. In the Americas in 2008, Brazil recorded the highest incidence of this disease, as well as the largest number of associated deaths ${ }^{1}$. Taking into account the lack of a vaccine against the disease, the most viable way to control dengue is to eliminate its main vector, the mosquito Aedes aegypti (Linnaeus, 1762) (Diptera, Culicidae) ${ }^{2,3}$.

Aedes aegypti multiplies in artificial containers, such as tanks, water-storage tanks, disused tires, vases, and various kinds of flasks ${ }^{4-6}$. As a consequence, A. aegypti is mainly controlled by assessing its breeding sites and sampling larvae and pupae in urban areas. This method is used to assess the levels of infestation in order to reduce the larvae and pupae and consequently minimize the risk of epidemics ${ }^{7}$. This strategy is adopted because the vector uses artificial containers that are often found within dwellings or in the peridomicile area as breeding sites ${ }^{8}$. This behavior assures the survival of the vector and reduces the efficiency of dengue $\mathrm{control}^{3}$. In regions where the water supply may be interrupted and people have low purchasing power, storage containers are the most important breeding sites for A. aegypti. In contrast, in large urban centers, the occurrence of artificial mosquito breeding sites is related to the enormous amounts of unusable, mainly disposable, materials ${ }^{9}$.

One of the most striking features of Brazil is the heterogeneity of its regions, with widely varying climate and socio-cultural conditions. Consequently, the prevention of dengue becomes complex because its occurrence is intimately related to the local conditions ${ }^{10}$. Therefore, studies at different sites throughout the country are useful to assess the process of $A$. aegypti adaptation in various situations. The understanding of these conditions may facilitate the determination of the most suitable control measures for each area of the country. 
In recent years, the State of Maranhão has recorded an increase in the number of dengue cases, including the hemorrhagic forms ${ }^{11}$; however, only a few studies have investigated $A$. aegypti and its reproductive mechanisms in this region. In view of this and of the eclectic behavior of $A$. aegypti in the use of domestic containers as breeding sites, and because of the different social factors, the aim of this study was to assess $A$. aegypti breeding sites and its productivity in the municipality of Caxias, Maranhão. This assessment included consideration of the effects of the dry and rainy seasons in this region.

\section{METHODS}

The study was carried out in the urban zone of the municipality of Caxias, from 2005 to 2007. Caxias is located in the eastern part of the State of Maranhão (451'32”S; 4321'2”W), and has a mean altitude of $67 \mathrm{~m}$ above sea level and an area of $5,313.2 \mathrm{~km}^{2}$. According to the Brazilian Institute of Geography and Statistics, the population of Caxias in 2010 totaled 155,129 inhabitants, including 118,534 in the urban zone and 36,595 in the rural zone, with a demographic density of 25 inhabitants $/ \mathrm{km}^{2}$ and an annual growth rate of $1.06 \%^{12}$. The climate is tropical, with a mean annual temperature of $28.4^{\circ} \mathrm{C}$ and a mean annual precipitation of $1,454.6 \mathrm{~mm}$, with 2 distinct seasons: a rainy period from January-June and a drier one from July-December ${ }^{13}$.

In general, the municipality of Caxias has a low socioeconomic level, with a human development index of 0.614 , demonstrating the state's penultimate place in the national ranking scale. The low quality of life in the city is apparent in the substandard basic sanitation, with an irregular water supply and garbage collection and disposal services $^{14}$.

In the first phase of the study, $A$. aegypti breeding sites were investigated in the dry (August-October 2005) and rainy (FebruaryApril 2006) seasons in 3 neighborhoods of Caxias: Cangalheiro, Campo de Belém, and Conjunto Habitacional Pampulha (CHP). These neighborhoods were selected because of their locations in different areas of the municipality and also because of differences in their physical aspects, in order to provide a representative sample of the study area.

The Cangalheiro neighborhood is located in the central part of the municipality, with a population of 4,134 and 1,627 buildings, mostly of masonry construction. The streets are paved, but deficiencies in sanitation include open sewage ditches, almost daily interruptions in the water supply, and irregular garbage collection services that do not reach all areas of the neighborhood.

The Campo de Belém neighborhood, located in the eastern part of the municipality, has a dense population of 6,297 and 2,478 houses, mostly of masonry construction but several (20\%) of cob (taipa) construction. The majority of houses have outdoor bathrooms, with large numbers of water-storage containers. Most of the streets are paved but some dirt roads remain, which turn to mud in the rainy season. Poor sanitation includes open sewage ditches and irregular water supply and trash collection.

The CHP neighborhood, in the southern part of the municipality, has 1,134 inhabitants and 562 buildings, all of masonry, with the homes constructed in the same pattern. The dwellings have better conditions than the other 2 neighborhoods, with indoor bathrooms and water tanks present in each home. The streets are unpaved and graveled. The water system is very irregular, with water supplied only during the night. Trash is collected regularly, but the sewage system is open, similar to that in the other neighborhoods. Of the 3 neighborhoods, CHP has the lowest population density, since it is the most recently built.

Between August 2005 and July 2006, a total of 900 properties were inspected, with 300 properties from each neighborhood. Each house was visited twice, once in the dry season (August-October 2005) and again in the rainy season (February-April 2006).

We employed the domicile visit method used by the Brazilian National Program for Dengue Control ${ }^{11}$. The house inspections were made in order to record potential A. aegypti breeding sites, i.e., containers, and to determine whether or not they were filled with water at the time of the visit and, thus, might be able to shelter the vector, in the intra- and peridomicile areas.

From the containers where immature forms of $A$. aegypti were found, all of the specimens were collected using plastic pipettes and sieves. The specimens were placed in test tubes containing $70 \%$ ethanol and were forwarded to the Laboratório de Entomologia Médica at the State University of Maranhão, where they were counted and identified at the species level with appropriate identification keys ${ }^{8}$.

From September 2006 through August 2007, collections were made in the Campo de Belém neighborhood to survey the containers and monitor the variation in larvae production during the course of 1 year, as well as the impact of control measures. A total of 300 properties were inspected in 5 periods of the year, termed cycles, with the following durations: $1^{\text {st }}$ period, September-October; $2^{\text {nd }}$ period, January; $3^{\text {rd }}$ period, March; $4^{\text {th }}$ period, May; and $5^{\text {th }}$ period, July-August. These cycles were established by the Municipal Dengue Control Program, and the domicile visit method was also employed in this series ${ }^{11}$. The previously described inspection method was used again.

The containers found on the properties were classified into 7 groups: I, storage (tanks, vats, water filters, pots, pails, and drums); II, flasks (bottles, cans, and plastics); III, fixed (drains, grease traps, and wells); IV, construction materials (construction materials and car parts); V, tires; VI, vases (plant pots and saucers); VII, others (every container that did not belong to the previous groups, such as Styrofoam ice chests and eggshells).

In order to determine the productivity $(\mathrm{p})$ of the breeding sites, the following equation was used: $p=\frac{X 1}{Z 1}$, where $X$ corresponds to the number of larvae and pupae found in a container in group I, and $\mathrm{Z}$ is the number of positive containers (containing larvae and/ or pupae) from the same group. The same calculation was made for each type of container.

The chi-square test of independence was used for comparisons among the different types of containers to verify the independence of the data among the groups. The chi-square test of adherence was used to compare seasons to verify if the differences found between seasons indeed resulted from chance. The tests were performed using the statistical package BioEstat 5.0 ${ }^{15}$.

\section{RESULTS}

In the survey of the 900 properties in the 2 seasons, a large number of potential A. aegypti breeding containers were found, with a total of 1,970 containers in the dry season and 1,836 in the rainy season. Among the different types of containers, those of 
the storage group were the most numerous, with a total of $55.7 \%$ $(\mathrm{n}=1,970)$ and $48.5 \%(\mathrm{n}=1,836)$ during the dry and rainy seasons, respectively (Table 1). Importantly, when the variation in the number of containers in each group in both seasons was analyzed, there was a trend toward an increase in the availability of containers from the tires, construction materials, storage, fixed containers, and "others" groups from the dry to the rainy season (Table 1).

Water-filled containers were significantly more abundant in the rainy season $(n=1,169 ; \mathrm{p}<0.05$; Table 1$)$. Storage containers were the predominant type in the dry season, comprising $73.8 \%$ $(\mathrm{n}=1,105)$, which was approximately 3 times the total number of all other types of containers found; these also predominated in the rainy season, comprising $69.7 \%(n=1,169)$ of all containers sampled $(\mathrm{p}<0.05$; Table 1$)$.

With respect to the seasonal variation in the availability of water-filled containers, each group, except for the vases and storage groups, showed different patterns in each season. Flasks constituted the highest number of water-filled containers during the dry season; however, with the onset of the rains, the tires, fixed, and others groups gained importance as breeding sites, since their numbers doubled during this season $(\mathrm{p}>0.05$; Table 1$)$.

With respect to the positive containers, during the dry season, although many containers were found filled with water, only the storage group contained larvae and pupae, with a mean of 23.72 larvae and/or pupae per container. In contrast, during the rainy season, immature stages of $A$. aegypti were recorded in all types of containers, except plant pots. Storage containers were the most important, comprising $66.6 \%$ of the containers found $(\mathrm{n}=99)$ ( $p>0.05$; Table 1). This number was more than double that in the dry season, and with 4 times as many larvae and/or pupae during this period (106.13; p $<0.05$; Table 1). These numbers suggest that with the increase in precipitation, the productivity of $A$. aegypti increases considerably.

In the intradomicile area, 1,125 and 1,064 containers were recorded in the dry and rainy seasons, respectively; however, these totals did not differ between the seasons. Storage containers were more than 3 times as numerous as the other groups in both seasons, accounting for $86.5 \%(\mathrm{n}=1,125)$ during the dry season and $84.6 \%$ $(\mathrm{n}=1,064)$ during the rainy season $(\mathrm{p}<0.05 ;$ Table 2$)$. A comparison of the remaining groups by season revealed that only the vase and others groups showed a seasonal relationship, being more numerous in the dry and rainy seasons, respectively $(\mathrm{p}<0.05$; Table 2$)$.

With respect to the number of water-filled containers in the dry and rainy seasons, the storage group was again the most important, comprising $90.6 \%(\mathrm{n}=978)$ and $89.4 \%(\mathrm{n}=975)$ of the total containers inspected, respectively $(\mathrm{p}<0.05$; Table 2$)$. Comparing the groups between seasons, flasks were the most abundant type of water-filled container during the rainy season, while tires were the most abundant type during the dry season $(\mathrm{p}<0.05$; Table 2$)$. The remaining groups did not show a seasonal pattern.

TABLE 1 - Total amount of inspected containers in the peridomicile area and Aedes aegypti productivity by container group during sampling in the dry and rainy seasons in the municipality of Caxias, State of Maranhão, Brazil.

\begin{tabular}{|c|c|c|c|c|c|c|c|c|c|c|c|c|}
\hline \multirow[b]{2}{*}{ Container group } & \multicolumn{3}{|c|}{ Inspected } & \multicolumn{3}{|c|}{ Filled with water } & \multicolumn{3}{|c|}{ Positives } & \multicolumn{3}{|c|}{ Productivity } \\
\hline & dry & rainy & $\mathbf{P}^{*}$ & dry & rainy & $\mathbf{P}^{*}$ & dry & rainy & $\mathbf{P}^{*}$ & dry & rainy & pa \\
\hline Vase & 17 & 11 & 0.3447 & 6 & 10 & 0.317 & 0.00 & 0.00 & & 0.00 & 0.00 & - \\
\hline Tires & 94 & 112 & 0.2362 & 3 & 27 & 0.000 & 0.00 & 6 & & 0.00 & 46.00 & - \\
\hline Construction materials & 7 & 46 & 0.0001 & 0 & 19 & - & 0.00 & 1 & & 0.00 & 7.00 & - \\
\hline Storage & 1,097 & 890 & 0.0001 & 816 & 812 & 0.9407 & 29 & 66 & 0.0001 & 23.72 & 106.13 & 0.0001 \\
\hline Fixed & 43 & 80 & 0.0012 & 43 & 64 & 0.042 & 0.00 & 1 & & 0.00 & 6.00 & - \\
\hline Others & 217 & 174 & 0.0337 & 87 & 136 & 0.001 & 0.00 & 18 & & 0.00 & 48.11 & - \\
\hline Total & 1,980 & 1,836 & 0.0206 & 1,105 & 1,469 & 0.0001 & 29 & 99 & 0.0001 & 23.72 & 83.20 & 0.0001 \\
\hline $\mathrm{P}^{* *}$ & $<0.0001$ & $<0.0001$ & & $<0.0001$ & $<0.0001$ & & & $<0.0001$ & & & $<0.0001$ & \\
\hline
\end{tabular}

TABLE 2 - Total amount of inspected containers in the intradomicile area and Aedes aegypti productivity by container group during sampling in the dry and rainy seasons in the municipality of Caxias, State of Maranhão, Brazil.

\begin{tabular}{|c|c|c|c|c|c|c|c|c|c|c|c|c|}
\hline \multirow[b]{2}{*}{ Container group } & \multicolumn{3}{|c|}{ Inspected } & \multicolumn{3}{|c|}{ Filled with water } & \multicolumn{3}{|c|}{ Positives } & \multicolumn{3}{|c|}{ Productivity } \\
\hline & dry & rainy & $\mathbf{P}^{*}$ & dry & rainy & $\mathbf{P}^{*}$ & dry & rainy & $\mathbf{P}^{*}$ & dry & rainy & pa \\
\hline Vases & 60 & 98 & 0.0032 & 45 & 65 & 0.0701 & 0 & 3 & na & 0 & 4.6 & na \\
\hline Flasks & 40 & 43 & 0.8262 & 10 & 24 & 0.0258 & 0 & 1 & na & 0 & 0 & na \\
\hline Tires & 15 & 9 & 0.3074 & 14 & 2 & 0.0060 & 0 & 0 & na & 0 & 0 & na \\
\hline Construction materials & 3 & 1 & na & 0 & 0 & na & 0 & 0 & na & 0 & 0 & na \\
\hline Fixed & 1 & 1 & na & 1 & 1 & na & 0 & 0 & na & 0 & 0 & na \\
\hline Others & 33 & 12 & 0.0029 & 22 & 11 & 0.0817 & 0 & 0 & na & 0 & 0 & na \\
\hline Total & 1,125 & 1,064 & 0.1997 & 978 & 975 & 0.9639 & 13 & 15 & 0.8501 & 7.9 & 112.96 & $<0.0001$ \\
\hline $\mathbf{P}^{* *}$ & $<0.0001$ & $<0.0001$ & & $<0.0001$ & $<0.0001$ & & na & $<0.0001$ & & na & $<0.0001$ & \\
\hline
\end{tabular}


The positive containers showed no significant seasonal differences ( $\mathrm{p}<0.05$; Table 2). During the dry season, only storage containers provided positive results, while they were the most important during the rainy season $(73.3 \%$; $\mathrm{n}=15$; $\mathrm{p}<0.05$; Table 2), with no seasonal difference in numbers. Although the number of storage containers did not differ between seasons, $\sim 10$ times more immature
TABLE 3 - Sampling cycles with the respective numbers of inspected and positive containers from peridomicile and intradomicile areas of 300 properties in the municipality of Caxias, State of Maranhão, Brazil, from September 2006 to August 2007.

\begin{tabular}{|c|c|c|c|c|c|c|}
\hline \multirow[b]{2}{*}{ Cycles (period) } & \multicolumn{3}{|c|}{ Containers filled with water } & \multicolumn{3}{|c|}{ Positive containers } \\
\hline & peridomicile & intradomicile & $\mathbf{P}^{*}$ & peridomicile & intradomicile & $\mathbf{P}^{*}$ \\
\hline $1^{\text {st }}($ Sep-Aug 06) & 666 & 676 & 0.8059 & 18 & 4 & $<0.0056$ \\
\hline $2^{\text {nd }}(\operatorname{Jan} 07)$ & 533 & 423 & 0.0004 & 52 & 15 & $<0.0001$ \\
\hline $3^{\text {rd }}($ Mar 07) & 461 & 496 & 0.2717 & 48 & 7 & $<0.0001$ \\
\hline $4^{\text {th }}($ May 07) & 497 & 548 & 0.1219 & 66 & 4 & $<0.0001$ \\
\hline $5^{\text {th }}($ Jul-Aug 07) & 422 & 637 & $<0.0001$ & 40 & 2 & $<0.0001$ \\
\hline Total & 2,579 & 2,780 & 0.0063 & 224 & 32 & $<0.0001$ \\
\hline $\mathrm{P}^{* *}$ & $<0.0001$ & $<0.0001$ & $\mathrm{P}^{* *}$ & $<0.0001$ & 0.0025 & \\
\hline
\end{tabular}

A. aegypti individuals were found in the rainy than in the dry season ( $\mathrm{p}<0.05$; Table 2). Notably, containers in the other groups also contained immature stages of $A$. aegypti in the rainy season, although in much lower numbers compared to the storage group.

In the peridomicile area, large numbers of water-filled containers were observed during the entire monitoring cycle, mainly in September-October when the highest number of filled containers was found, comprising more than $25.8 \%$ $(\mathrm{n}=2,579)$ of the total number of containers $(\mathrm{p}<0.05$; Table 3$)$. In the intradomicile area, this monitoring cycle was also the most important, with $24.3 \%$ of all the monitored containers. A comparison of both sites (i.e., peri- and intradomicile) revealed a significant difference between the domiciles in the $2^{\text {nd }}$ (January 2007) and $5^{\text {th }}$ (July-August 2007) cycles, with the greatest difference observed in the peri- and intradomicile areas ( $p<0.05$; Table 3 ). These observations indicate that the difference in the availability of containers in the peri- and intradomicile environments may be related to the time of year.

A total of 224 and 32 positive containers were found in the peri- and intradomicile areas, respectively, with significantly more containers in the peridomicile area $(p<0.05$; Table 3 ). In the peridomicile area, although the highest number of water-filled containers was recorded in the $1^{\text {st }}$ monitoring cycle, the highest number of immature $A$. aegypti was found in the $4^{\text {th }}$ cycle (May 2007), with $29.4 \%(\mathrm{n}=224$; $\mathrm{p}<0.05$; Table 3). The productivity of immature A. aegypti differed in the intradomicile area and was highest in the $2^{\text {nd }}$ monitoring cycle (January 2007), i.e., 46.9\% $(n=32$; $p<0.05$; Table 3 ). Positive containers predominated in the peridomicile area in all of the monitoring cycles.

Concerning the type of positive containers recorded during the inspection cycles of the breeding sites, the flasks and tires groups included low numbers of positive containers. Storage containers predominated, comprising $94 \%(n=256)$ of the total number of positive containers. The highest proportion of positive containers was found during the $2^{\text {nd }}$ monitoring cycle (January 2007), comprising 26.2\% ( $\mathrm{n}=241$; $\mathrm{p}<0.05$; Table 4). In the peridomicile area, the proportion of positive containers was significantly higher than in the intradomicile area, with $86.7 \%(n=241 ; p<0.05$; Table 4). Positive storage containers predominated in the peridomicile area in all of the cycles $(\mathrm{p}<0.05$; Table 4$)$.
TABLE 4 - Sampling cycles, showing the number of positive storage containers from the peridomicile and intradomicile areas of $\mathbf{3 0 0}$ properties in the municipality of Caxias, State of Maranhão, Brazil, from September 2006 to August 2007.

\begin{tabular}{lccc}
\hline Cycle & Dwelling site & Storage & $\mathbf{P}^{*}$ \\
\hline $1^{\text {st }}$ & peridomicile & 18 & $<0.0056$ \\
& intradomicile & 4 & \\
\hline $2^{\text {nd }}$ & peridomicile & 48 & $<0.0001$ \\
& intradomicile & 15 & \\
\hline $3^{\text {rd }}$ & peridomicile & 46 & $<0.0001$ \\
& intradomicile & 7 & \\
\hline $4^{\text {th }}$ & peridomicile & 57 & $<0.0001$ \\
& intradomicile & 4 & \\
\hline $5^{\text {th }}$ & peridomicile & 39 & $<0.0001$ \\
& intradomicile & 2 & \\
\hline Total & peridomicile & 208 & $<0.0001$ \\
& intradomicile & 32 & \\
\hline $\mathbf{P}^{* *}$ & peridomicile & $<0.0001$ & \\
& intradomicile & $<0.0001$ & \\
\hline $\mathbf{P}^{*}:$ adherence test; $\mathbf{P}^{* *}:$ independence test. & &
\end{tabular}

The occurrence of dengue is directly related to the presence of its vector $A$. aegypti. This mosquito can persist and disperse widely within Brazil as a result of the wide availability of artificial containers in urban areas, a phenomenon that is well described and discussed in the literature $\mathrm{e}^{8,16,17}$.

This study in the City of Caxias, Maranhão, showed that although dengue control campaigns emphasize the importance of water containers in the dispersal of the dengue vector, residences still contain large numbers of containers with the potential to serve as breeding habitats of $A$. aegypti. These containers were present in the intradomicile and peridomicile environments, in all of the neighborhoods studied. They provide perfect conditions to shelter the vector because they contain large amounts of exposed clean water with no protection, which facilitates the access of the mosquito to the water. These very numerous storage areas are the sites where larvae and pupae are most often found, and consequently produce high numbers of mosquitoes in the peri- and intradomicile areas and in the dry and rainy seasons.

However, the tires, construction material, fixed, and others groups were also important potential breeding sites of $A$. aegypti in the rainy season, since immature stages of the vector were found in

\section{DISCUSSION}


these containers only in this season. These types of containers are discarded inappropriately, generally around residences and with no protection, and the regular rains in this period ensure that they retain water long enough for $A$. aegypti to breed.

This study showed that the large number of water-storage containers in Caxias is a result of the lack of water, a recurring situation in the 3 neighborhoods studied. Because of the water-supply problem, the residents must maintain large numbers of drinkingwater containers at their residences for daily use, principally largevolume containers such as tanks, barrels, and buckets. Residents with a very low socio-economic level are unable to maintain adequate water-storage facilities and therefore store water in inappropriate ways, which creates ideal breeding conditions for A. aegypti. The presence of these storage containers is the determining factor for the maintenance of the vector in these areas.

Other investigators have described a similar situation in different locations in the northeast region of Brazil ${ }^{18-20}$. In the State of Ceará, containers used to store water, such as tanks, drums, and rooftop water tanks, predominated as the principal breeding sites of A. aegypti $i^{18,21}$. The problem of water supply was also mentioned as one of the aggravating factors in necessitating the large number of these containers in residences, as was their predominant role as breeding $\operatorname{sites}^{18,19}$. In other countries, such as Cuba and Nicaragua, water-storage containers were most often found to contain the largest number of immature $A$. aegypti $i^{21-23}$.

Different situations have been described for other regions of Brazil. In the southeast, the flasks and drains groups were most commonly found to have immature forms of the vector in domiciles in the City of São Paulo, and a similar result was noted for the grease traps in the City of Rio de Janeiro ${ }^{24,25}$. Another study carried out in the north, in Manaus, Amazonas, found that the flasks and tires groups accounted for the largest number of larvae and pupae ${ }^{17}$. This shows that the potential types of breeding sites of A. aegypti vary according to the environmental conditions in each region.

With respect to the number of breeding sites present in the 2 seasons, in the rainy season, the number increased by $\sim 3$-fold and the productivity of larvae was $\sim 14$-fold higher.

One aspect of this study requiring emphasis is the existence of positive breeding sites that persist during the dry period. In spite of the high temperatures at this time of year, the immature forms continue to exploit the large water containers, assuring the continuity of the vector from one season to the next. Other studies have also noted this factor in helping to maintain the vector in the northeast region of the country ${ }^{24,26,27}$.

The scenario described in this region shows that the effectiveness of control measures is impaired as a function of this dynamic of the breeding sites. On the other hand, the frequent lack of water means that the population must store sufficient water for each individual family unit.

The data from this study indicate the urgent need for investment in the region to address this controversial situation that has dogged the northeast of Brazil since the time that $A$. aegypti first infested the urban areas in this region. Storage tanks cannot continue to be manufactured by local artisans because, in this form, they are ideal breeding grounds for mosquitoes. It is imperative to introduce a model residential water-storage container that is completely screened, but still easy to use. The federal, state, and municipal governments should invest in a fiberglass model with a screen cover that is practical for drawing water, in order to succeed in controlling dengue in this region.

The data from this study, together with a bibliographic review of the subject, indicate that the whole problem of dengue in the northeast of Brazil arises because of the lack of access to fresh water, with $A$. aegypti colonizing water-storage facilities in urban and peri-urban areas. This study also points to the need to educate the population in order to prevent the vector from breeding in and around their homes. These campaigns must be carried out during the entire year because, as observed here, some breeding containers are positive for immature $A$. aegypti throughout the year. The present scheduling of intermittent control campaigns contributes to the lack of success in controlling the disease $\mathrm{e}^{28}$.

Because the lack of fresh water is related to public policies that require a long period to implement, 1 way to reduce the dispersal of A. aegypti is to intensify vector-control campaigns. The population in areas affected by water shortages should be advised to clean their water-storage units appropriately, and thus prevent the vector from reproducing and developing.

\section{CONFLICT OF INTEREST}

The authors declare that there is no conflict of interest.

\section{REFERENCES}

1. Roriz-Cruz M, Sprinz E, Rosset I, Goldani L, Teixeira MG. Dengue and a primary care: a tale of two cities. Bull World Health 2010; 88:244-244.

2. Teixeira MG, Barreto ML, Costa MCN, Ferreira LDA, Vasconcelos PFC. Avaliação de impacto de ações de combate ao Aedes aegypti na cidade de Salvador, Bahia. Rev Bras Epidemiol 2002; 5:108-115.

3. Braga IA, Valle D. Aedes aegypti: vigilância, monitoramento da resistência e alternativas de controle no Brasil. Epidemiol Serv Saude 2007; 16:295-302.

4. Focks DA, Chadee DD. Pupal. Pupal survey: an epidemiologically significant surveillance method for Aedes aegypti: an ex-ample using data from Trinidad. Am J Trop Med Hyg 1997; 56:159-167.

5. Focks DA, Sackett SR, Bailey DL, Dame DA. Observations on container-breeding mosquitoes in New Orleans, Louisiana, with an estimate of the population density of Aedes aegypti (L.). Am J Trop Med Hyg 1981; 30:1329-1335.

6. Gubler DJ. Dengue and Dengue Hemorrhagic Fever. Clin Microbiol Rev 1997; 11:480-496.

7. Braga IA Valle D. Aedes aegypti: inseticidas, mecanismos de ação e resistência. Epidemiol Serv Saude 2007; 16:279-293.

8. Consoli RAGB, Lourenço-de-Oliveira R. Principais mosquitos de importância sanitária no Brasil. Rio de Janeiro: FIOCRUZ; 1994.

9. Dolanisio MR, Glasser CM. Vigilância entomológica e controle de vetores do dengue. Rev Bras Entomol 2000; 5:3.

10. Quintero J, Carrrasquilha G, Suaréz R, Gonzaléz C, Olano VA. An ecosystemic approach to evaluating ecological, socioeconomic and group dynamics affecting the prevalence of Aedes aegypti in two Colombian towns. Cad Saude Publica 2009; 1:S93-S103.

11. Ministério da Saúde. Sistema Nacional de Vigilância em Saúde. Relatório de Situação Maranhão. Brasília: Ministério da Saúde; 2009.

12. Instituto Brasileiro de Geografia e Estatística (IBGE). Dados referentes à cidade de Caxias-MA. Senso Demográfico 2000 [Internet]. [Cited 2010 July 31]. Available from: http://www.ibge.gov.br/cidadesat/default.php/.

13. Gerência de Planejamento e Desenvolvimento Econômico (GEPLAN). Atlas do Maranhão. $2^{\text {nd }}$ ed. São Luis: GEPLAN. Governo do Estado do Maranhão; 2002.

14. Feitosa AC, Trovão JR. Atlas Escolar do Maranhão. Espaço Geo-Histórico e Cultural. João Pessoa: Grafset; 2006. 
15. Ayres M, Ayres JRM, Ayres DL, Santos AAS. BioEstat 5: Aplicações Estatísticas nas Áreas das Ciências Biológicas e Médicas. $5^{\text {th }}$. ed. Belém-PA: Publicações Avulsas do Mamirau; 2008.

16. Tauil PL. Aspectos críticos para o controle do dengue no Brasil. Cad Saude Publica 2002; 18:867-871.

17. Pinheiro VCS, Tadei WP. Frequency, diversity, and productivity study on the Aedes aegypti most preferred containers in the city of Manaus, Amazonas, Brazil. Rev Inst Med Trop São Paulo 2002; 44:245-250.

18. Pamplona LGC, Lima JWO, Cunha JCL, Santana EWP. Avaliação do impacto na infestação por Aedes aegypti em tanques de cimento do Município de Canindé, Ceará, Brasil, após a utilização do peixe Betta splendens como alternativa de controle biológico. Rev Soc Bras Med Trop 2004; 37:400-404.

19. Caprara A, Lima JWO, Marinho ACP, Calvasina PG, Landim LP, Sommerfeld J. Abastecimento irregular de água, seu uso domiciliar e dengue: Uma pesquisa biossocial no nordeste do Brasil. Cad Saude Publica 2009; 25:125-136.

20. Carneiro EWB, Lima JWO, Pontes RJS. Prevalecia da infestação de diferentes tipos de depósitos pelo Aedes aegypti na cidade de fortaleza. Rev Soc Bras Med Trop 2000; 33:407.

21. Martins VEP, Alencar CHM, Facó PEG, Dutra RF, Alves CR, Pontes RJS, et al Distribuição espacial e características dos criadouros de Aedes albopictus e Aedes aegypti em Fortaleza, estado do Ceará. Rev Soc Bras Med Trop 2010; 43:73-77.

22. Hammond SN, Gordon AL, Lugo EC, Moreno G, Kuan GM, López MM, et al Characterization of Aedes agypti (Dipetera: Culcidae) Production Sites in Urban Nicarágua. Entomol Society America 2007; 44:851-860.

23. Marquetti CM, Nunez N, Aguilera L, Fuentes O, Navarro A. Incidência de culicideos em una zona urbana de ciudad de la Habana durante 1995. Rev Cubana Med Trop 1998; 50:138-142.

24. Silva VC, Scherer PO, Falcão SS, Alencar J, Cunha SP, Rodrigues IM, et al. Diversidade de criadouros e tipos de imóveis freqüentados por Aedes albopictus e Aedes aegypti. Rev Saude Publica 2006; 40:1106-1111.

25. Maciel-de-Freitas R, Marques WA, Peres RC, Cunha SP, Oliveira LR. Variation in I (Diptera: Culicidae) container productivity in a slum and a suburban district of Rio de Janeiro during dry and wet seasons. Mem Inst Oswaldo Cruz 2007; 102:489-496.

26. Glasser CM, Gomes AC. Clima e sobreposição de distribuição de Aedes aegypti e Aedes albopictus na infestação do Estado de São Paulo. Rev Saude Publica 2002; 36:166-172.

27. Serpa LLN, Costa KVRM, Voltilini JC, Kakitani I. Variação Sazonal de Aedes aegypti e Aedes albopictus no município de Potim. Rev Saude Publica 2006; 40:1101-1105

28. Lenzi MF, Coura LC. Prevenção do dengue: informação em foco. Rev Soc Bras Med Trop 2004; 37:343-350. 